OPEN ACCESS

Edited by:

Annadel Salvio Cabanban, Wetlands International, Netherlands

Reviewed by:

Jonathan A. Anticamara, University of the Philippines Diliman, Philippines

Fabio Pranovi,

Ca' Foscari University of Venice, Italy

*Correspondence:

Elizabeth Drury O'Neill elizabeth.druryoneill@su.se

Specialty section:

This article was submitted to Marine Fisheries, Aquaculture and Living Resources,

a section of the journal

Frontiers in Marine Science

Received: 09 November 2018

Accepted: 22 July 2019

Published: 14 August 2019

Citation:

Drury O'Neill E, Lindahl T, Daw T,

Crona B, Ferrer AJG and Pomeroy $R$

(2019) An Experimental Approach

to Exploring Market Responses

in Small-Scale Fishing Communities.

Front. Mar. Sci. 6:491

doi: 10.3389/fmars.2019.00491

\section{An Experimental Approach to Exploring Market Responses in Small-Scale Fishing Communities}

\author{
Elizabeth Drury O'Neill1*, Therese Lindahl1,2, Tim Daw ${ }^{1}$, Beatrice Crona ${ }^{1,3}$, \\ Alice Joan G. Ferrer ${ }^{4}$ and Robert Pomeroy ${ }^{5}$ \\ ${ }^{1}$ Stockholm Resilience Centre, Stockholm University, Stockholm, Sweden, ${ }^{2}$ The Beijer Institute of Ecological Economics, \\ The Royal Swedish Academy of Sciences, Stockholm, Sweden, ${ }^{3}$ Global Economic Dynamics and the Biosphere, The Royal \\ Swedish Academy of Sciences, Stockholm, Sweden, ${ }^{4}$ Division of Social Sciences, University of the Philippines Visayas, \\ Miagao, Philippines, ${ }^{5}$ Connecticut Sea Grant, University of Connecticut, Groton, CT, United States
}

Small-scale fishing communities are increasingly connected to international seafood trade via exports in a growing global market. Understanding how this connectedness impacts local fishery systems, both socially and ecologically, has become a necessary challenge for fishery governance. Market prices are a potential mechanism by which global market demands are transferred to small-scale fishery actors. In most small-scale fisheries (SSF) this happens through various traders (intermediaries, middlemen/women, or patrons). By financing fishing operations, buying and selling products and transferring market information, traders can actively pass international market signals, such as price, to fishers. How these signals influence fishers' decisions and the consequent fishing efforts, is still poorly understood yet significant for future social-ecological sustainability. This paper uses an economic framed field experiment, in combination with interviews, to shed light on this. It does so in the context of the Philippine patronclient "suki" arrangement. Over 250 fishers in Concepcion, lloilo were asked in an economic experiment, to make decisions about fuel loans in light of changing market prices. Interviews with participants and their patrons gathered additional information on relevant contextual variables potentially influencing borrowing. They included fisher characteristics and socio-economic conditions. Contrary to our hypotheses, fishers showed no response in their borrowing behavior to experimental price changes. Instead, gender and the previous experiment round were predictive of their choice of loans in the experiment. We explore possible reasons for this and discuss potential implications for social-ecological sustainability and fishery governance.

Keywords: global seafood trade, behavioral economic experiments, gender roles, patron-client relationship, Philippines, market price, fisher behavior

\section{INTRODUCTION}

Small-scale fisheries (SSF) are increasingly linked to expanding global seafood trade and, as such, are also more affected by various market features at these larger scales, such as fluctuating demands, volatile prices, or eco-certification schemes (Berkes et al., 2006; Crona et al., 2015, 2016). The small-scale nature of these fisheries means their connections to international seafood trade 
also have implications for human development, local exploitation, and food security (Béné et al., 2016). For example, with trade liberalization, prices received by small-scale fishers are no longer domestically set, but are affected by international markets, and thus much less connected to, or driven by, local supply and overexploitation (Thanh and Flaaten, 2012). The exact ways in which fishers' extractive behavior and subsequent ecological sustainability is affected by market integration remains unclear. One often cited mechanism through which international markets penetrate SSF societies is price. Existing literature on SSF suggests that fishers change their efforts as a result of economic incentives (Andersson and Ngazi, 1998; Gössling, 2003; Kooiman et al., 2005; Johnson, 2010; Máñez and Ferse, 2010; Brewer, 2011), but their specific responses (a behavior) to fluctuating world market prices, and the effect of these responses on resource extraction, remain uncertain. In fact empirical literature documents a wide range of responses by fishers to such price changes (Pollnac and Crawford, 2000; Salas et al., 2004; Miñarro et al., 2016), indicating that our understanding of this complex phenomena is still incomplete.

Studying the effects of price changes on fishing and ecosystem dynamics is complex because market incentives trickle through the social fabric of fishing societies and are generally transferred to fishers via trading agents positioned between the fishers and local, regional, or international market systems. Within SSF, these traders (often referred to as middlemen, patrons or intermediaries) provide a range of both social and financial services. They represent a key link in transferring global market incentives to production, which they do largely though financing and loans, e.g., providing new vessels and gear (Johnson, 2010; Máñez and Ferse, 2010). The reciprocal services provided by traders to fishers, in return for loyalty, supply, favors and other benefits, enable fishing populations around the world to operate in settings where institutional, and social support may be scarce (Carnaje, 2007; Johnson, 2010; Ruddle, 2011). They also buffer variabilities in income and livelihood due to drivers such as seasons, policies or natural disasters (Drury O'Neill et al., 2019). These reciprocal relationships are often termed patron-client relationships. They vary in their degree of formalization or institutionalization and can range from the provision of petty cash advances to fisher acquaintances, to acting as godparents to fishers' children due to inherited family business ties. Research has flagged that patron-client relationships can be both exploitative and beneficial depending on the context (Hardiman, 1996; Johnson, 2010; Ferse et al., 2014; Nurdin and Grydehøj, 2014; Miñarro et al., 2016; Purcell et al., 2017). Yet how they mediate fluctuating price changes and transfer these to fishers, and how this in turn influences extractive patterns is poorly understood. This paper takes a first step in addressing this gap by using methods from behavioral economics to examine the influence of seafood prices on fishing efforts through patron's provision of fuel loans, and how this is filtered by fisher characteristics and the patron-client system. More specifically we ask:

- To what extent does a change in the price, filtered through a patron (under uncertain catch rates) affect fishers' loan taking behavior, and consequently their assumed fishing effort?

- What household and individual level characteristics (e.g., nature of patron-client relationship, economic conditions, gender, gear type, and financial risk preferences) predict fishers' propensity to take fuel loans from patrons?

In this study behavior is conceptualized as an observable output of a decision-making process; a cognitive process involving either analytical thought, conscious or unconscious drivers or feelings as well as recognition-based or by the book decisions e.g., based on social roles (Weber and Lindemann, 2007). We assume that loan-taking decisions are directly translated into action or behavior.

Contrary to theoretical approaches that assume "rational actors," behavioral economic experiments can capture the bounded rationality of decision makers and test the influence of a particular variable (such as price), while accounting for other factors (such as gear type, gender norms, risk attitudes, and household funds or assets owned), which have all been argued as potentially important in determining fishers' financial and extractive decisions (Platteau, 1989; Eggert and Lokina, 2007; Fabinyi, 2007; Croson and Gneezy, 2009; Ruddle, 2011; Charness and Gneezy, 2012; Miñarro et al., 2016; Kininmonth et al., 2017). Yet, despite the promise of behavioral economic experiments to understand complex social-ecological causality, the SSF literature has, to date, been dominated by a "rational actor" model of decision-making (Fulton et al., 2011). Similarly, many fishery market interventions have also been informed by economic theories resting on assumptions of rationality, even though such assumptions of actor behavior are unlikely to hold true in the context of 'small-scale societies' like SSF (Henrich et al., 2001; Jentoft and Eide, 2011). This paper aims to shed new light on the complex causality between international seafood trade and local fishing and loaning behavior by making use of experimental methods. We believe this provides a novel addition to SSF scholars struggling to understand these complex dynamics, but also provides knowledge on fisher and patron responses to market fluctuations, to better inform attempts to develop sustainable fishery governance interventions, as noted by Kininmonth et al. (2017).

The paper first elaborates on our choice of methodology in the Methodological approach section. The Case Study subsection to the Experiment Participants subsection then situates and justifies the experimental design within the context of the Province of Iloilo, the fisheries of the area, the patron-client system (known locally as the suki system), and how patrons themselves respond to price fluctuations. Based on our two overarching research questions we develop a set of hypotheses regarding how our focal variables relate to loan taking and the extractive behavior of fishers. We anchor these in existing theories or empirics and describe the experimental design we used to test them. Our results are then elaborated in relation to the context of the field sites and discussed in relation to other studies on SSF and trade. We finish with a short reflection on the limitations in the experimental setting and design. 


\section{METHODOLOGICAL APPROACH}

We applied a mixed methods approach, systematically testing fishers' responses to price changes (filtered through a patron) in behavioral economic experiments while contextualizing the observed behavior with interviews and observational data. We used a price increase as a proxy for a new connection to a global market. We focused on fishers' decisions to take different size fuel loans (which implies different fishing efforts) from their patrons for fishing (the most frequent loan-type in the study area) in response to uncertain catch rates and changing prices. This was done as a means to isolate the trickle down of market prices through the patron-client link, and how this translates into fishing effort. Our choice of this design is further motivated below, in relation to the real-world context of the Iloilo region. Figure 1 presents an overarching conceptual framework for the paper which reflects our understanding of the system and the transfer of price to patrons, fishers, the potential contextual influences, and consequent fisher decisions.

Interviews or questionnaires can be inadequate at addressing fishers' behavior and decision-making (one part of human behavior) in relation to market drivers as a result of hypothetical biases associated with data collection (Schulze et al., 1981), and our own extensive empirical work has repeatedly shown this. Behavioral economic experiments instead allow the construction of counterfactual narratives (Harrison and List, 2004), eliminating the hypothetical nature of interview techniques and, through the use of real money, makes the monetary consequences of participant's decisions more real (Kagel and Roth, 2016). Our approach rests on combining interviews, observations and discussions (to provide the background context for both validating the experimental design, and later anchoring the interpretation of results), with so called economic "framed field experiments" (Harrison and List, 2004). We do this in the Philippines where the suki system is well-documented as an institutionalized patronclient relationship, prevalent in markets across the country (Davis, 1973; Pomeroy, 1992; Hendriks, 1994; Carnaje, 2007; Ferolin and Dunaway, 2013).

\section{Case Study Area}

The field work took place in the municipality of Concepcion located in the northern part of Iloilo Province (Figure 2), which borders the Visayan Sea, home to one of the top three fishing grounds of the Philippines as well as the world's center of marine biodiversity (Ferrer, 2009, 2016; NEDA, 2011). A large part of Concepcion's population of 43,159 as of 2015 (Iloilo Provincial Annual Profile, 2015) lives offshore across 12 island barangays (the smallest administrative unit in the Philippines) and is supported largely by fishing, with limited farming due to poor terrain. The fisheries are dominated by small-scale fishers (using boats $\leq 3 \mathrm{GT}$, locally termed municipal) who sell almost all their catch and leave negligible amounts for household consumption. The Visayan Sea area, in general, is one of the top seafood exporters in the Philippines, thus highly connected to national and international market systems (Hernando, 2005; NEDA, 2011).

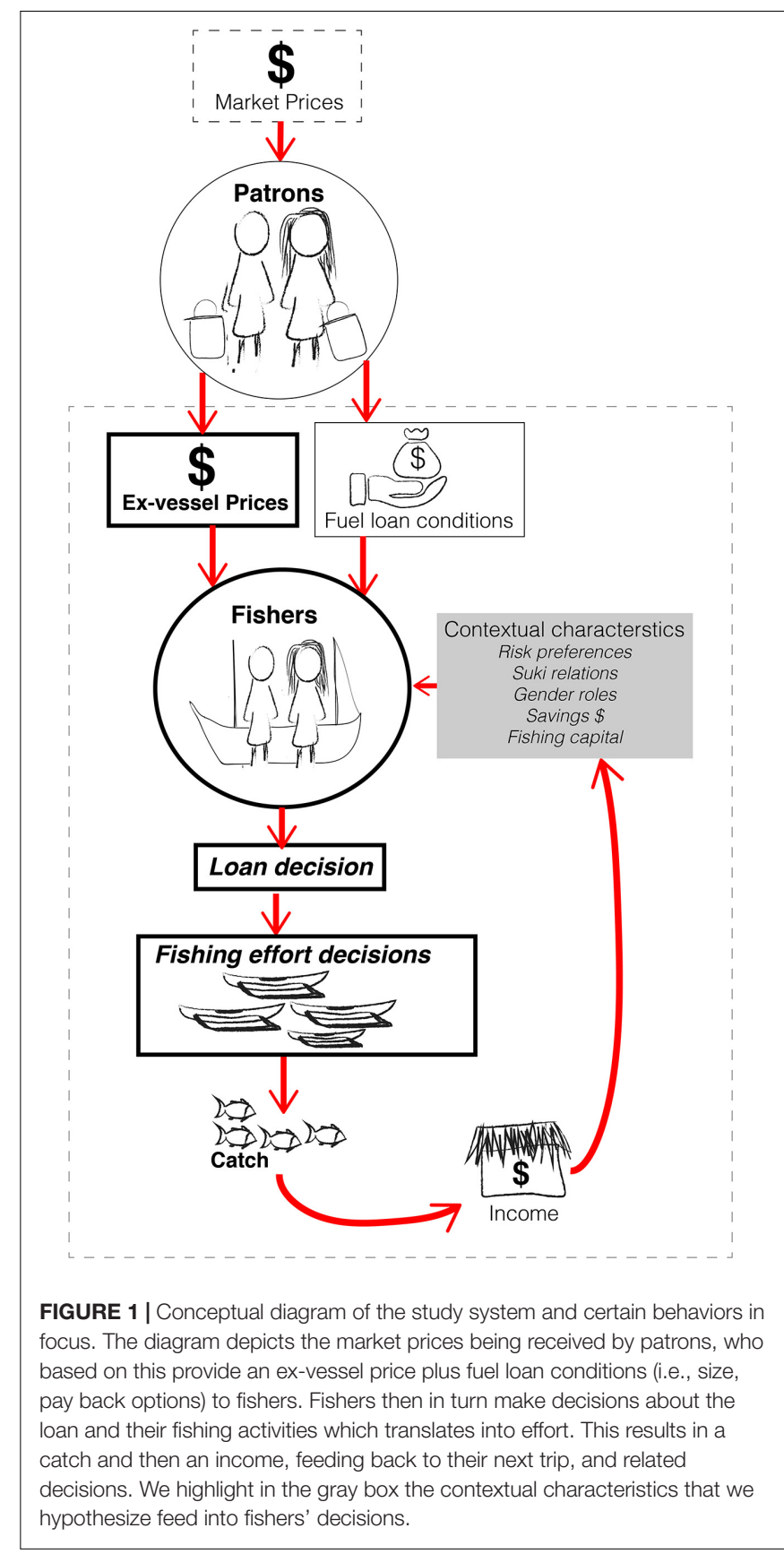

Four main fishing styles or types ( $71 \%$ of participants) were identified through structured interviews (post-experiment) amongst the fishers in our sample, summarized in Table $\mathbf{1}$ below, which are representative of the fleets around Concepcion.

We selected 11 island sitios (settlements) as field sites according to their relative distance to the main fish port and market (so as to capture a range of distances) and representativeness of diversity in the fishing gears, vessels and styles found in Concepcion. Fishers in each sitio were recruited to the experiment through the Barangay Captain- the official gatekeeper, elected by the barangay residents to politically represent the barangay at the municipal level. 


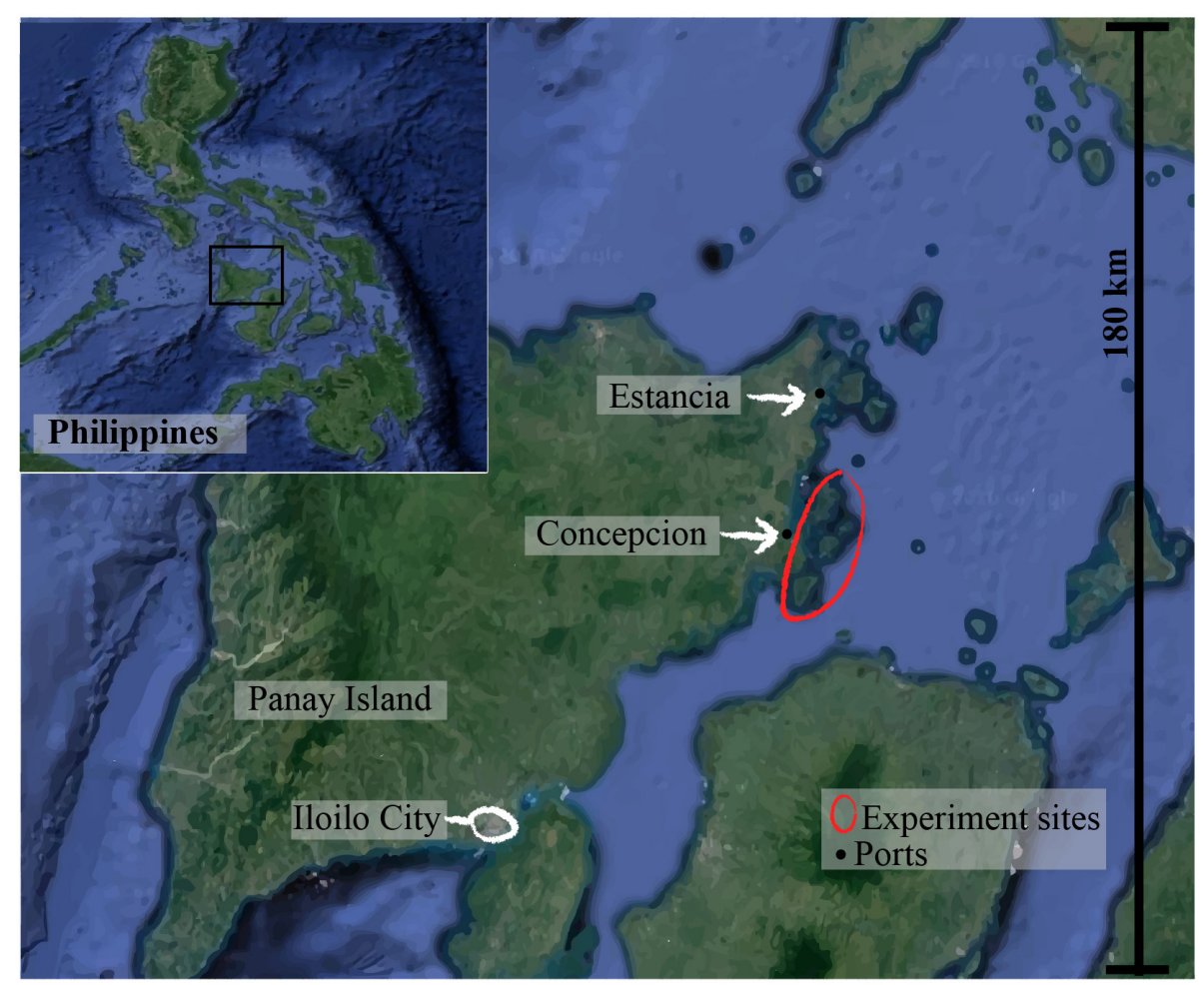

FIGURE 2 | Panay island location in Philippines (inset). The Capital of the main province on Panay Island, Iloilo, can be seen circled in white to the south- Iloilo City. Concepcion is located on the North Eastern seaboard as is Estancia- the other major, and larger fishing port and town to the North of it. The area where the experimental sites are is circled in red.

TABLE 1 | Key features of the four main fishing styles in the study area and proportion of fishers in our sample (and proportion of total women and total men) engaged in each.

\begin{tabular}{|c|c|c|c|c|}
\hline \multicolumn{5}{|c|}{ Main fishing styles of sampled fishers } \\
\hline Gear (Hiligaynon, English) & $\begin{array}{l}\text { Palubog bottom set } \\
\text { gillnets }\end{array}$ & Taga hook \& line & Trol baby trawl & Bubu fish trap \\
\hline $\begin{array}{l}\text { Main target spp. } \\
\text { (Hiligaynon/English/scientific } \\
\text { name) }\end{array}$ & $\begin{array}{l}\text { Guma-a/short bodied } \\
\text { mackerel/Rastrelliger } \\
\text { spp. Latab/silver } \\
\text { biddy/Gerres spp. }\end{array}$ & $\begin{array}{l}\text { Lagaw/threadfin } \\
\text { bream/Nemipterus spp. }\end{array}$ & Lokus/squid/Photololigo spp. & $\begin{array}{l}\text { Opusan/monocle } \\
\text { bream/Scolopsis spp. }\end{array}$ \\
\hline Average vessel length (m) & $6-7$ & $6-8$ & $8-9$ & $5.5-7$ \\
\hline \% Total fishers (women/men) & $21(12 / 23)$ & $19(17 / 25)$ & $17(11 / 35)$ & $14(14 / 14)$ \\
\hline
\end{tabular}

Seafood products are typically landed in island barangays or at the fish ports of Concepcion, Estancia or San Dionisio. There are two main types of patrons in this study - buyers and brokers. In barangays, "buyers" (fish traders based from their homes) largely purchase the product. At ports "brokers" are the main trader type. Buyers will sell to brokers or to retailers and wholesalers on the mainland either every day or every week, depending on if they dry the products in their homes. The brokers sell the fresh products most frequently to bigger brokers in Iloilo City, Manila, Manapla, Cadiz, and other cities. Wholesalers largely deal in dry produce and supply national markets, supermarkets and also export. Processing companies in Iloilo Province buy directly from fishers and barangays buyers, targeting largely squid and small pelagic fish for international export to Taiwan and China. Figure 3 depicts the value chain and the sales paths involved, which are further described by Drury O'Neill et al. (2018). This study specifically focuses on the relationship between the fisher and his/her immediate trader (patron- red in Figure 3).

\section{Situating the Experiments in the Conception Trade System - Elaboration of the Patron-Client Relationship and Price Change}

This section describes the patron-client system and loan dynamics in Concepcion based on complimentary data collection (described under the section "Formulating Hypotheses to Test With the Experiment") to situate the experiment and support assumptions of the experimental design, e.g., that patrons 


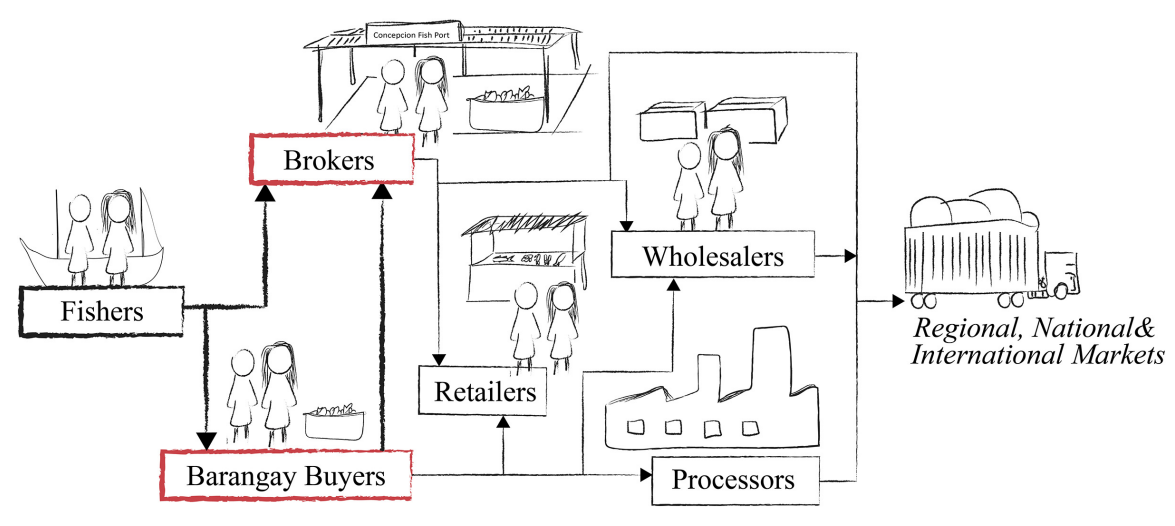

FIGURE 3 | Conceptualization of the market system in the Concepcion Municipality, Philippines. Arrows represent the sales paths of the product being sold. The larger more bolded lines and arrows represent the actors in this paper and study - the fishers, barangay buyers, and brokers. The red indicates the patrons.

transmit prices to fishers. Complimentary data was acquired through various interview-types and discussions.

The value chain includes various forms of informal financing arrangements from traders (patrons) to fishers, which form part of the patron-client suki system. For details on the suki system in other fisheries in the Philippines (see Pomeroy, 1990, 1992). Our field experiments focus on individual fishers' decision-making in relation to the loans and ex-vessel prices offered through this institutionalized suki system. While the word suki can refer to both a regular customer, as well as the relationship itself (Hendriks, 1994). Suki in this paper refers to the relationship. In the Visayas this relationship is characterized by interest-free loans, regularity, trust, personal connectedness and selectivity, where only certain patrons are finally selected as partners (Carnaje, 2007). After loans are repaid, clients (fishers in this case) are typically free to take another lone or switch to a different patron, although a debt of gratitude or "utang na loob" may keep them tied (Davis, 1973; Carnaje, 2007).

Loan sizes and frequencies are decided according to fishers' catch rates, fishers' needs and requests, the patron's available capital, and the fisher's loyalty to patrons (i.e., their commitment to land their product only to that patron). Financing includes most commonly, on a daily or weekly basis, the provision of fuel loans ( $80 \%$ of fisher participants) and gear and equipment (once or a few times a year) as well as family-related loans (typically weekly) (53-55\% of fishers). Thus, our experiment focused on loans for fuel because of their high level of familiarity to most participants. Similarly, their agency over loan size was anchored in the common practices of the area. Pay back of suki loans typically happen upon landing - but if landings are very low then patrons will waive repayments or reduce them until catch rates increase. Patron brokers usually use sales prices of their own customers to calculate gross value of the landed product and take a percentage from this value for their services- so market prices are directly passed to fishers and barangay buyers.

\section{Experiment Participants}

We ran the experiment with 251 fishers in over 25 experimental sessions in 11 sitios within four barangays. Demographic characteristics of participants are summarized in Supplementary Table S1. Most participants were full time fishers and a quarter had secondary income sources from sari sari stores (local shops), carpentry, processing seafood and a range of other activities including farming and state employment. Although women partake in these fishery value chains, fishing remains male dominated in terms of numbers (no official statistics on the number of fishermen and women). We believe our sample with $22.7 \%$ women reflects gender ratios in fishing in the area.

\section{Formulating Hypotheses to Test With the Experiment}

In this section we operationalize our research questions by outlining six hypotheses based on previous literature and/or previous fieldwork in the area, which are to be tested by the experiment. The latter includes interviews with fishers, traders, governmental-agents and NGOs on trade relations, and market dynamics (Drury O'Neill et al., 2018). Table 2 describes these hypotheses and how they were operationalized with variables to be tested.

- Price: Fishers will be more likely to choose a bigger fuel loan from their patrons following a price increase and less likely following a price drop. We assumed choosing a bigger fuel loan for fishing translates into an increase in effort (time spent at sea or distance traveled) with the intention of landing more (expensive) fish. This increased landing potential is included in the experiment if fishers take the bigger loan. Literature shows fishers responding to prices and high demand by focusing effort on high-value species (Miñarro et al., 2016). Platteau (1989) also finds that when demand is high, especially as fisheries open up to the global market, loan-based selling arrangements with patrons increase.

In addition to price effects, contextual fishing, household and individual characteristics were hypothesized to influence loantaking behavior:

- Financial risk preference: Risk-seeking fishers are more likely to take the bigger loan, independent of the price increase. Risk 


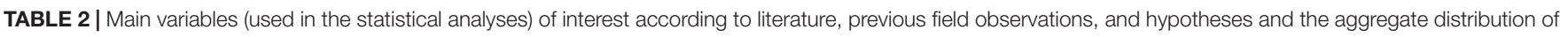
the variables across the participants in our sample.

\begin{tabular}{|c|c|c|c|c|}
\hline \multirow{4}{*}{$\begin{array}{l}\text { Factor hypothesized or } \\
\text { observed to have } \\
\text { relationship with loan taking } \\
\text { Price }\end{array}$} & \multirow{4}{*}{$\begin{array}{l}\text { Hypothesized relationship and } \\
\text { direction } \\
\text { Price increase = increase in bigger } \\
\text { loan taking Price } \\
\text { decrease = decrease in bigger loan } \\
\text { taking }\end{array}$} & \multirow{4}{*}{$\begin{array}{l}\text { Variable to measure } \\
\text { Number of times bigger loans } \\
\text { were taken by individual fishers- } \\
\text { continuous variable }\end{array}$} & \multicolumn{2}{|c|}{ Proportions of participants \% } \\
\hline & & & Control & 30 \\
\hline & & & Treatment 1 (price increase) & 34 \\
\hline & & & $\begin{array}{l}\text { Treatment } 2 \text { (price increase \& } \\
\text { decrease) }\end{array}$ & 33 \\
\hline \multirow[t]{4}{*}{ Suki relationship strength } & \multirow{4}{*}{$\begin{array}{l}\text { Stronger tie = increased bigger loan } \\
\text { taking }\end{array}$} & \multirow{4}{*}{$\begin{array}{l}\text { Categorical survey responses } \\
\text { scored and summed }\end{array}$} & Rank $0=$ no relationship & 9 \\
\hline & & & $\begin{array}{l}\text { Rank } 1 \text { = flexible relation, easy to } \\
\text { change to patron }\end{array}$ & 9 \\
\hline & & & $\begin{array}{l}\text { Rank } 2 \text { = medium flexibility, } \\
\text { somewhat likely they could change }\end{array}$ & 18 \\
\hline & & & $\begin{array}{l}\text { Rank } 3=\text { not flexible, they are not } \\
\text { likely to change patron according to } \\
\text { prices, better loans etc }\end{array}$ & 65 \\
\hline \multirow[t]{3}{*}{ Financial risk preference } & \multirow{3}{*}{$\begin{array}{l}\text { Risk seeking \& neutral = increased } \\
\text { bigger loan taking }\end{array}$} & \multirow{3}{*}{$\begin{array}{l}\text { Gamble choice in } \\
\text { post-experiment risk } \\
\text { assessment- categorical variable }\end{array}$} & $0=$ risk Averse & 59 \\
\hline & & & $1=$ risk neutral & 21 \\
\hline & & & $2=$ risk seeking & 20 \\
\hline Gender & Men $=$ increased bigger loan taking & Binary variable- men or women & Women & 23 (women) \\
\hline \multirow[t]{2}{*}{ Household savings } & \multirow{2}{*}{$\begin{array}{l}\text { Above average savings = increased } \\
\text { bigger loan taking }\end{array}$} & \multirow{2}{*}{$\begin{array}{l}\text { Savings last month in PHP- } \\
\text { continuous variable }\end{array}$} & Above average & 38 \\
\hline & & & Below average & 61 \\
\hline \multirow[t]{4}{*}{ Gear type } & \multirow{4}{*}{$\begin{array}{l}\text { Category } 1=\text { decreased bigger } \\
\text { loan taking Category } \\
2-4=\text { increased bigger loan taking }\end{array}$} & \multirow[t]{4}{*}{4 types of gear categories } & 1-Lines/spears & 26 \\
\hline & & & 2-Traps & 15 \\
\hline & & & 3-Large active nets & 26 \\
\hline & & & 4-Set/drift/drive in gill nets & 33 \\
\hline
\end{tabular}

TABLE 3 | Summary of loan size, catches and incomes (payoffs) for each loan size option, with the base price, and the increased price in the experiment.

\begin{tabular}{|c|c|c|c|c|c|c|c|c|}
\hline \multicolumn{9}{|c|}{ Summary of choices and payoffs } \\
\hline \multirow[t]{2}{*}{ Loan type } & \multirow{2}{*}{$\begin{array}{l}\text { Fuel loan } \\
\text { size (PHP) }\end{array}$} & \multirow{2}{*}{$\begin{array}{l}\text { Catch } \\
\text { range }\end{array}$} & \multicolumn{3}{|c|}{ Base price 2 PHP } & \multicolumn{3}{|c|}{ High price 4 PHP } \\
\hline & & & $\begin{array}{c}\text { Gross income } \\
\text { range (PHP) }\end{array}$ & $\begin{array}{l}\text { Net income } \\
\text { range }(\mathrm{PHP})\end{array}$ & $\begin{array}{c}\text { Mean net } \\
\text { income (PHP) }\end{array}$ & $\begin{array}{c}\text { Gross income } \\
\text { range (PHP) }\end{array}$ & $\begin{array}{l}\text { Net income } \\
\text { range (PHP) }\end{array}$ & $\begin{array}{c}\text { Mean net } \\
\text { profit (PHP) }\end{array}$ \\
\hline Big & 20 & $0-20$ & $0-40$ & -20 to +20 & 0 & $0-80$ & 40 to +60 & 20 \\
\hline Small & 5 & $0-10$ & $0-20$ & -5 to +15 & 5 & \multicolumn{3}{|c|}{ Same as base price } \\
\hline None & 0 & 0 & 0 & 0 & 0 & \multicolumn{3}{|c|}{ Same as base price } \\
\hline
\end{tabular}

PHP, Philippine pesos.

neutral fishers are more likely to take the bigger loan when the price increases (c.f. Eggert and Martinsson, 2004; Eggert and Lokina, 2007). This hypothesis follows from our experimental design and an expected utility framework, in which, riskloving fishers prefer more risky alternatives. Taking a bigger loan is associated with a high risk of indebtedness with no price increase (see Table 3). When the price increases it becomes the best option for expected returns.

- Suki relationship strength: Fishers with stronger relationships to their patron (i.e., more inflexible) are more likely to take bigger fuel loans. In real life, larger loans indicate a willingness to stay in a suki relationship, because they imply deepening the indebted relationship with the patron (field observations, Concepcion, Iloilo, and Philippines). Fishers wishing to switch patron (weaker suki relations) are less likely to go for big loans in real life as they want to avoid further indebtedness as to untie themselves. Although loans are paid back each round in the experiment we hypothesized a tendency toward the smaller or larger size loan as result of real-life tendencies. Although the literature does not point to the size of loan fishers would take as a result of their relationship there is evidence of patrons and clients desiring continued and persistent loan-taking, avoiding full repayments to ensure a continued relationship (Merlijn, 1989; Platteau, 1989).

- Gender: Men are more likely to take bigger fuel loans than women as they are more financially risk seeking. They are also more likely to take a bigger loan to increase their chances to land more catch due to cultural norms associated with gender in fishing in the Philippines. The literature review by Croson and Gneezy (2009) shows that men are more financially risk seeking than women in risk tasks like gambling and lotteries, although with WEIRD [Western Educated Industrialized Rich Democratic (Henrich et al., 2001)] participants. Charness and Gneezy (2012) find the same gender-influenced risk tendencies in a compilation of results from 10 experiments based on investment behavior. 
Literature specific to the Philippines and fishing communities states that masculinity is directly enacted through fishing where the ability to catch fish, especially more fish, is an expression of male success (Dumont, 1992; Russell, 1997; Fabinyi, 2007).

- Household savings: Household savings are expected to play a role in predicting bigger loan taking, however, the direction is unclear as evidence and observations are ambiguous. Fishers with more savings could be more willing to take a bigger fuel loan because they have more capacity to pay back and are less risk averse. Literature provides evidence that the income-poor are more financially risk averse. For example, Haushofer and Fehr (2014) using datasets from multiple countries conclude that income poverty leads to risk-averse decision-making. Yesuf and Bluffstone (2009) find high risk aversion in rural Ethiopian farming communities with low-incomes and in a similar agricultural setting in Nigeria Adubi (1996) finds the higher the income the higher the capacity of the farmer to assume risk in their farming. On the other hand, fishers with more savings in the month before the experiment could be less likely to take a big loan as they are less in need of cash to run their vessels (field observations, Concepcion, Iloilo, and Philippines).

- Fishing capital- gear/vessel: Fishers with labor intensive/larger vessel type fishing activities (active nets, drag/drift/set nets, and trap) are more likely to take bigger loans because they are used to borrowing more to finance their fishing operations. Line fishers and smaller vessel users are less likely to take big loans as they need relatively little finance. This variable might have a relationship with risk preferencesEggert and Lokina (2007) find that more capitalized Tanzanian fishers i.e., those with more expensive gears and outboard motors are more risk seeking. They compare this with similar results amongst Swedish fishers using trawls, whom are less risk averse than gill net or trap users (Eggert and Martinsson, 2004).

\section{EXPERIMENTAL AND COMPLIMENTARY METHODS}

The following sections "Experimental and Complimentary Methods" and "Data Treatment and Analysis," which include the experimental design, methods of data collection, treatment and statistical analysis, are based on and follow the convention of economic experiments (for examples in a SSF context see: Carpenter and Seki, 2011; Noussair et al., 2015; Lindahl and Jarungrattanapong, 2018).

\section{Experimental Design}

In this experiment, fishers made individual decisions repeatedly over 12 rounds to take a big or small fuel loan from a patron or refrain from fishing. Fishers made profit based on fuel costs and catches which were randomly drawn each round. Higher catches were possible for fishers taking a big loan (Table 3). Participants were divided into three treatment groups who experienced (1) no price change throughout the experiment (control), (2) a price increase (treatment 1 in round 4) for those fishers taking a big loan, and (3) a price increase and then decrease (treatment 2 , increase in round 4 and decrease in round 8) during the experiment. Supplementary Text S2 describes the experimental procedure in detail.

The experiment was framed to resemble the real-world context, while isolating individual fishers' decisions. This individualized approach overlooked some system complexity such as interactions between fishers, or discussions within households, but helped us to understand individual fisher decision-making in relation to loan taking and ensured a sample size that allowed statistical analysis. Figure $\mathbf{4}$ conceptualizes the experimental decisions and variables that fishers faced in all treatment groups over all rounds.

To keep the framing anchored in their own fishing experience fishers were given a general introduction (all done orally in a group setting) that informed them a patron offers them a small fuel loan or a bigger fuel loan that will enable them to make larger catches (see Supplementary Text S3 for the actual instructions used, translated from Hiligaynon to English). In each round (12 rounds in total), each fisher was informed of the fish prices and asked to decide whether to take a big or small loan, or not take a loan and not go fishing for that round. Catches were drawn randomly from a distribution depending on loan size with larger catches possible for bigger loans (Table 3). The no loan choice mainly served as an exit option. Loans were paid back in full at the end of each round from the sale of the catch and net as well as cumulative income were recorded for the individual fisher to see. Each round was separate and incomes from previous rounds could not be used in following ones. To ensure that everyone understood the experiment, examples of these calculations were done as a group on whiteboards twice before sessions started.

Before deployment in the field, the experiments were piloted on four occasions, twice with students at a Swedish university, once with Filipino students and once in the field with fishers.

Catches were reported in a unitless scale of 0-20 where 0 was nothing and 20 was a "bumper" catch (which was only possible to land with a big loan). Fishers were asked to relate the catch scale to the range of catches experienced in their current real-life fishing (this interpretation was collected in kilograms in the postexperiment interview described in the section "Complimentary Data Collection"). We did this so as to better interpret their experimental decisions in relation to their real-life fishing trips and assess their understanding of the experiment.

Catches for big and small loans in each round were drawn from discrete uniform distributions; $[0,10]$ for the small loan and $[0,20]$ for the big loan. There was an equal likelihood of all catch rates in each round. In order to facilitate 10 participants per session and to minimize noise from individual randomly variable catches (and increase the statistical power to detect treatment effects), the big and small loan catches for each round were drawn in advance and were the same across all participants, see Figure 5. Catches for each round were revealed to participants after they had made their decisions.

In rounds with a higher price (i.e., rounds 4-12 in treatment 1 , rounds $4-7$ in treatment 2 ) the ex-vessel price was doubled, 


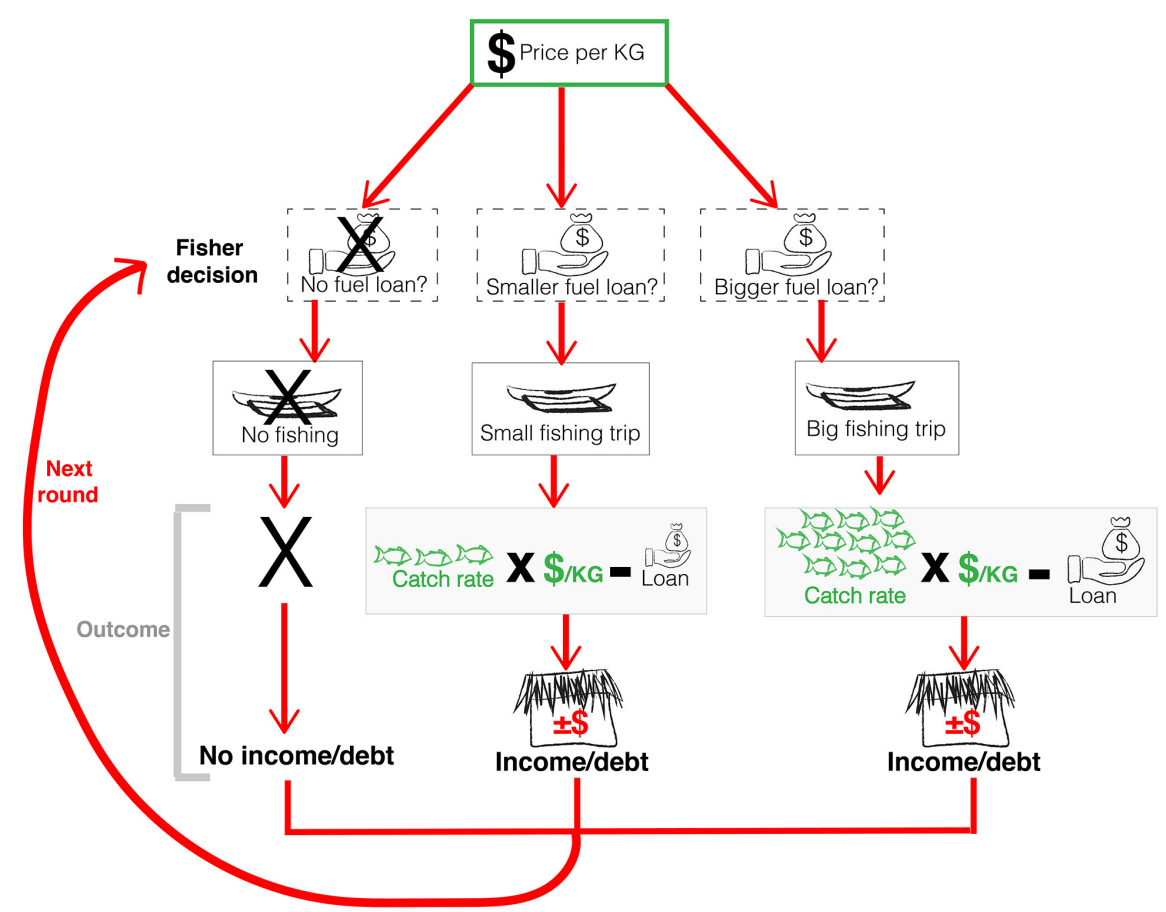

FIGURE 4 | Shows the experimental situation - the decisions and variables within the experiment. Fishers receive a price per kg from patrons. With this price they also get offered a fuel loan. They need to decide whether they take a loan at all or take a smaller or bigger loan (the dashed lines show the decision the fishers must take in the experiment). Depending on that choice they can fish on a smaller trip, a bigger trip or not at all. Those that fish have the chance of a smaller or bigger catch rate depending on the fuel. The catch they end up with is multiplied by the given price per kg and the fuel loan debt is removed. Fishers thus end up with an income or debt or nothing (if they did not fish). They see the outcome and then make the same decisions for the next round. The green represents the experimental variables that are changed in the experiment- the catch rate is random (selected before the experiment) and the price is increased or decreased by the experimenters.

but only if fishers took a bigger loan (reflecting being able to target the more valuable/demanded species). Participants in all treatments were given the same introduction and told that the prices may change; they did not know which direction. At the start of the session and between each round participants were presented with paper decision cards along with catches and incomes from the last round, current prices for the next round and current cumulative income. Fishers indicated their individual decision by ticking a box for big/small/no loan on their paper decision cards. Fishers were not allowed to communicate with each other and contact between participants was minimized throughout the experiment.

Participants were assigned to the sessions according to their availability. Each session was accorded a treatment. We switched treatment after every session to avoid discussion or strategizing amongst past and future participants. Sessions were run individually during the morning and afternoon and participants were not aware which treatment group they belonged to.

Price treatments were introduced at the relevant round with the same information. The control group experienced no change in price throughout the experiment. In the first phase (rounds 1-4) prices were constant across all treatments. In rounds 4-7, prices doubled for treatment 1 and 2 but only the big fuel loan trip (i.e., fishers would have to take a big loan to capture the higher price). In rounds 8-12 prices remained high for treatment 1 and reverted to the original level for treatment 2 .

\section{Financial Risk Preference Elicitation}

Financial risk preferences of individual fishers were captured at the end of each session using a simple probability decision task before fishers completed the post-experiment interview (see Supplementary Text S4, Supplementary Figure S4, and Supplementary Table S4 for details on the decisions tasks). This probability weighting method is standard for measuring financial, and other risk preferences in economics and psychology (Wakker, 2010; Cardenas and Carpenter, 2013; Kahneman and Tversky, 2013). The decision task was explained orally like the experiment itself using written examples on a whiteboard. Fishers were told that one of them would be chosen at random to win the actual money associated with the task ( 1 in 10 chance), which would be added to their earnings from the experiment. Fishers wrote down their choice on their decision cards before the draw was carried out. Two framings were used, one based on a decision task represented by lottery balls similar to (Cardenas and Carpenter, 2013) and the second framed as a fishing trip (Eggert and Lokina, 2007) but using the same numerical options. These different framings were used to test if fishers preferred and/or better understood the more abstract decision task with the lottery 
balls or the more realistically framed task with fishing trip incomes. Each treatment was equally divided between risk framings and participants in the same session experienced the same risk framing.

\section{Complimentary Data Collection}

Complimentary data was collected through interviews, focus group discussions and observations to allow us to anchor both our experimental design and the discussion of results in relation to the suki system, financing and various socio-economic factors of interest (see Supplementary Table S5 for details on the different methods employed).

Seven focus group discussions were done during field visits the month before experiments with the general fishing community which informed the interpretation of experiment results through subjects such as gender roles, scenarios around the suki system and global market demands (See Supplementary Table S5). Furthermore, short structured interviews were carried out with all participants after each experimental session (see Supplementary Material S6 for the post-experiment survey/interview instrument) to collect attributes needed to test our hypotheses. See Table 2 for variables used and their hypothesized importance for loan taking behavior. Additionally, fishers' own interpretations of the catch rates, trip types and associated incomes during the experiment were elicited to assess how, and if, they could translate the experiment to their real-life contexts. This is a common practice to validate the experimental design (Garzon et al., 2016; Lindahl and Jarungrattanapong, 2018). Every third session was followed by either a focus group discussion (Supplementary Material S7) or a semi-structured interview (Supplementary Material S8), so as to ensure one was carried out at each sitio but not every session. The post-experiment group discussions gave instant feedback on the salience of the experiment for participants, as well as a general sense of how fishing communities deal with changes in prices, and the ecosystem. The semi-structured interviews complimented the focus groups with individual level details on the same topics. Interview respondents were selected with the help of local "gatekeepers" (i.e., the barangay officials) to represent key informants, with a greater knowledge of the general system and those who also interested and articulate in sharing this knowledge.

Before we ran the experiments we also held in-depth interviews with patrons (brokers and buyers in the local barangays) to capture the dynamics surrounding their business structures (Supplementary Material S9). Understanding how financers make decisions about fuel loans and how they have responded when prices have changed dramatically in the past was important in verifying the experimental design.

\section{DATA TREATMENT AND ANALYSIS}

All post-experiment interview and experimental data were collated in a spreadsheet while qualitative interviews and focus group data were translated and transcribed from voice

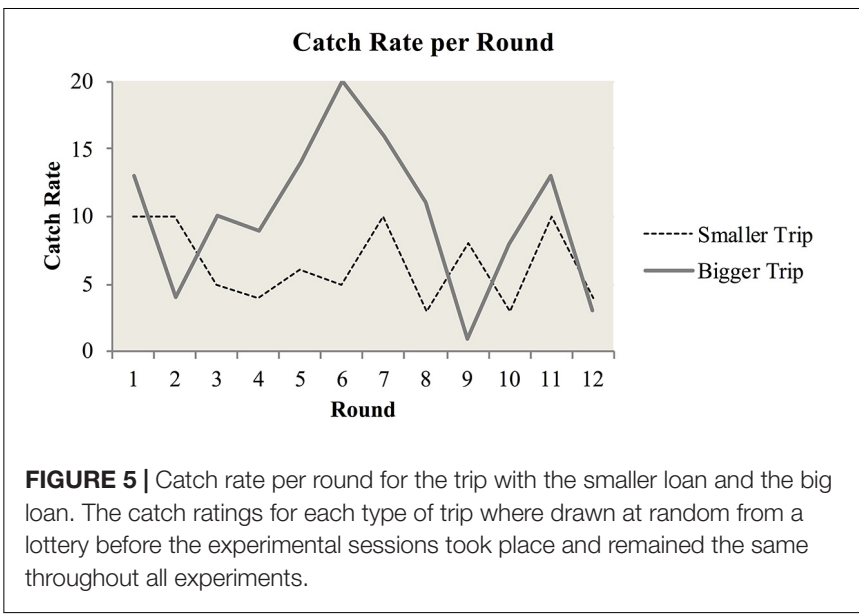

recordings and notes taken during sessions. Demographics including age, gender, education, number of household income activities, savings and number of dependents was tested with Kruskal-Wallis, Wilcoxon, Pearson chi-squared, and Fisher's exact (when less than five observations were made) tests in R (Ripley, 2001) to check for potential structural differences between treatments. Effects of the risk preference task framings on measured risk preference were tested between framings across all treatments with a Pearson chi-squared test. The hypothesized relationship between risk preferences with fishing capital, gender, and savings were also investigated with the appropriate tests to understand if there were associations as hypothesized.

We initially tested for differences of average treatment effects (price changes) on decisions before analyzing and testing for other predictors using regression analysis. We tested whether decisions (the number of times small, big, and no loan choice were chosen in each phase) differed between treatments. Each loan choice made by a participant (12 in total) was treated as a single observation and frequencies of no/small/big loan choices were tested against treatments for each phase. Next, we compared the frequency that individual fishers took small, big and no loans, throughout the experiment across treatments. Finally, we tested the frequency of big loan choices per phase between treatments according to the main price hypothesis.

We then built binomial regression models $[\operatorname{glm}()$ function in $\mathrm{R}$ ] with the decision of a big over a small loan as the dependent variable and independent variables according to our hypotheses. We removed the small number of fishers who took no loan because it was not the main variable of interest, and few people choose this option ( $n=19$ in round $1, n=23$ in round 4). We assessed model prediction power and fit using McFadden pseudo $r$ squared statistics [pR2()] and log likelihood ratio tests [lr.test()]. All contextual variables (see Table 2) were investigated for collinearity using the VIF (variance inflation factor), function vif(). None of the resulting VIF values were over 1.5 suggesting no or inconsequential collinearity (Mela and Kopalle, 2002). 
The first regression model tested effects of individual and household characteristics on the odds of choosing a big loan in round 1, before any different payoffs had been experienced.

Because the same randomized sequence of catch rates was used in all experiments, and because the big and small loan catches were different (Figure 5), each participant experienced payoffs that did not vary randomly between individuals but depended deterministically on the sequence of choices they made in each round. Thus, throughout the experiment, choices in each round may have been influenced by these non-random payoff experiences from earlier rounds. The possible different sequences of choices increased by a power of three with each subsequent round. As a result, we focused analysis on rounds 1 to 4 , before the number of possible combinations of previous decisions became too many to control for.

Although we worked through examples with the participants before beginning, as a precaution against the start-of-experiment effect, we repeated Model 1 with round 2 choices (Model 2). In this model we controlled for the effects of the participants first choice by adding this round 1 choice as an independent variable.

In the next steps (Models 3-5) we tested for effects of the price increase on the likelihood of choosing a big loan. The dependent variable for Models 3-5 was whether a big loan was chosen in round 4 , the first round when prices increased. Model 3 tested the effect of the price rise (i.e., treatment 1 and 2) while Models 4 and 5 additionally controlled for the choices made and experiences of rounds 1-3, by including the choice sequence from these rounds as nominal dummy variables. Although there were $3^{3}=27$ possible sequences of choices for rounds $1-3$, the six most common combinations of choices captured a large proportion (91\%) of the participants (see Supplementary Table S10 for the top six options). Thus, we added these six sequences as dummy variables, and excluded fishers that chose other sequences in rounds 1-3 from Models 4 and 5. This maintained the largest possible sample size while minimizing the degrees of freedom needed to incorporate previous choices in rounds 1-3. To interpret the effect of these choice sequences, we looked at the payoff fishers received each round and cumulatively, which indicated if they had a good (above average pay off) or bad (below average payoff) experience of the experiment. Model 5 additionally controlled for the effect of contextual variables we hypothesized as predictive of loan taking.

In the following section we present the models in relation to how they answer the hypotheses stated in section "Situating the Experiments in the Conception Trade System - Elaboration of the Patron-Client Relationship and Price Change" (i.e., not in numerical order).

\section{RESULTS}

We first introduce the results of the risk elicitation task, because this is subsequently used as an explanatory variable in the regression models. We then respond to each of the six hypotheses, first the main treatment- fish price, which is accounted for in
Models 3-5, followed by the contextual fishing, household and individual characteristics, used to build Models 1, 2, and 5.

\section{Financial Risk Preferences in the Sample}

Among the 251 fishers, 59.3\% were financially risk averse, $20.7 \%$ risk neutral and $19.9 \%$ risk seeking (Table 2). Financial risk aversion amongst men and women was similar ( $p$-value: 0.40 ). Monthly savings and gear type also did not have a relationship with financial risk aversion, as hypothesized ( $p$ values: 0.39-0.59). There was no difference in financial risk preference between the two different framings used ( $p$-value: 0.64). In the focus group discussions, fishers who completed either framing generally agreed they were easy to understand and that both were similar to gambling, which is a common activity in many sitios. No strong preference for either framing emerged from any of these discussions, thus both an abstract and real-life framing appeared suitable in assessing financial risk in the certain field context. For these reasons, we do not subsequently distinguish between the two framings in our regressions including risk aversion.

\section{Predicting Loan Taking}

The Main Hypothesis- Price (Treatment) Effect

Throughout the experiment participants, on average, chose the big loan 32\% (SD 27\%) of the 12 rounds, the small loan 59\% (SD $28 \%$ ) of the time and opted out with no loan $8 \%$ (SD $15 \%)$ of the time. There was no statistical difference between treatments in these choices (Supplementary Table S11, $p$-values: 0.69-0.84), nor was there a difference in the frequency of big loan choices between treatments for the different phases (Supplementary Table S11, $p$-values: 0.22-0.64). From this crude first step no treatment effect of the price increase or decrease was evident, but we revisit the potential influence on prices in the subsequent regression analyses where we control for potential confounding variables.

Models 3-5 all included the price variable, and none showed any treatment effects from the price changes. In fact, a price increase did not predict fishers taking a big loan in round 4 (Models 3-5 Table 4 - all model outputs can be found in Supplementary Tables S12, S13) even when contextualized variables and choices in the previous rounds (1-3) were considered (Table 4). On the basis of these findings we reject the first hypothesis that price change appears to have had no effect on fishers' loan taking behavior.

\section{Hypotheses Based on Contextual Variables and Their Influence on Loans and Fishing}

The strength of the risk type, suki relationship, gender, savings, and gear type (thus operation style), were not significantly predictive of fishers' initial choices in round 1 (Model 1 , Table 4). Moreover, the likelihood ratio test suggested that we could not reject a hypothesis of no association for Model 1 (9.1610, $p=0.5169)$.

In Model 2 gender and gear type were weakly significant showing that women were less likely to choose the big loan over the small loan and fishers using traps were more likely to take big 
TABLE 4 | Summary of model results showing the variables used in the regressions and which ones came out as predictive of bigger loan choices in round 1,2 , or 4.

\begin{tabular}{|c|c|c|c|c|c|c|c|c|}
\hline & Round & Previous choice & Price & Gender & Gear & Suki strength & Risk type & Savings \\
\hline Model $1 n=233$ & 1 & & & NS & NS & NS & NS & NS \\
\hline Model $2 n=233$ & 2 & Big loan***(2.644) & & Women*(-1.70) & Traps*(1.79) & NS & NS & NS \\
\hline Model $3 n=229$ & 4 & & NS & & & & & \\
\hline
\end{tabular}

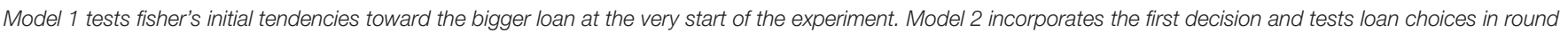

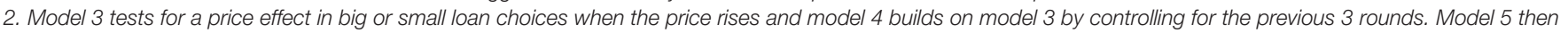

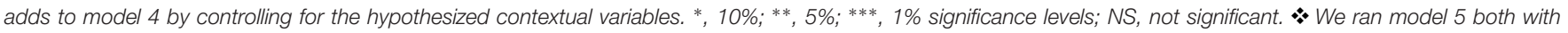

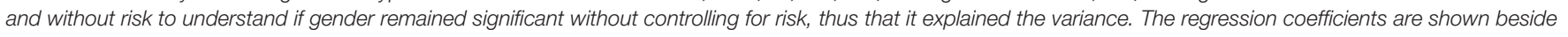
significant variables.

loans. The log likelihood ratio test showed we could reject a null model (of no association) in Model 2 (24.786, $p=0.01587$ ).

Model 5 indicated at the $1 \%$ significance level that, after controlling for choices in rounds $1-3$, women were much less likely to go for a big loan in the fourth round, supporting our hypothesis 4 that gender is a predictor of loan-taking decisions. We investigated this gendered result further and saw a clear pattern - that men much more frequently went for the big loan throughout the experiment, although, no gender difference could be detected in the first loan decisions (Model 1). Over half of the sampled women took the small loan for the first three rounds consecutively and in round 4, 94\% made this choice again. Women chose small loans significantly more frequently (78\%) than men (54\%) across all 12 rounds and large loans significantly less frequently (20\%) than men (36\%) (for all tests $p<0.01$ ).

Although we did find the that average years in a financing relation increased alongside the inflexibility of the arrangement (significant differences between the relationship lengths according to the suki ranks $0-3, p<0.001)$ we could not accept a hypothesis that fishers in inflexible suki relationships were more likely to take a bigger loan over a smaller loan when offered higher prices (Models 2 and 5). Additionally, risk type by itself was not a predictor for taking a big loan. All risk types went for the bigger loan between 30 and $39 \%$ of the time ( $p$-value: 0.27 ).

We therefore reject the hypotheses that the contextual variables of financial risk type, suki relationship "strength," household savings, and gear type had little or any effect on loan taking behavior.

We cannot reject hypothesis 4 however, as gender does have an effect on loan taking, and in our experiment, men are more likely to take a bigger loan.

\section{Previous Experimental Choices by Fishers as an Additional Predictor of Behavior}

In Model 2 we took account of the decision in the first round and saw that the previous choices significantly predicted fishers' decisions. Taking a big loan in the first period predicted the likelihood of taking a big loan in the second round (even though the actual return of the big loan in the first period was rather low at $6 \mathrm{PHP}$ ).

In Models 4 and 5 choices in the first three rounds were predictive of the choice in round 4 whether or not contextual variables were accounted for. Small-small-big, smallbig-big and big-big-big strongly predicted the big loan decision in round 4 (Model 4). Big-big-big and small-small-big loan choices remained strongly significant, especially the big-only combination, in Model 5 where gear, gender, suki relationship, risk and savings were controlled for.

These three choices (small-small-big; small-big-big; and bigbig-big) were made largely by men (56 men six women). Cumulative payoffs for these three choices were 30 PHP, 3 PHP, and -6 PHP, respectively, thus they represented quite different experiences in terms of realized catches and revenues (see Supplementary Table $\mathbf{S 1 0}$ for the expected and realized catches, the payoffs per round and the cumulative payoffs). As noted, the most predictive sequence for taking a big loan in round 4 was to take a big loan for all three first rounds (with a cumulative payoffs of $-6 \mathrm{PHP}$ ) - showing a subset of participants (17 men and two women) who persistently chose the big loan despite a negative cumulative payoff. Thus, fishers were more likely to take big loans if they took them in previous rounds (Model 2, 4, and $5)$, even though outcomes of taking them were variable.

In summary, taking a large loan was not affected by a price increase. Instead it was strongly predicted by the previous choices and by gender, with men taking more big loans. The gender effect supports our hypothesis, but this is not explained by higher financial risk seeking preferences amongst men.

\section{DISCUSSION}

\section{Are Prices a Short-Term Incentive for Small-Scale Fishers?}

We expected fishers to take a larger fuel loan (and thus increase their potential ability to catch more fish) in response to increasing economic incentives, operationalized here through the price of fish. But this is not what we found in the experiment. 
Our results reflect some previous literature examining fishers' short-term behavior in relation to a range of factors, including their fishing activities and market incentives. Salas et al. (2004) also had unexpected results in their study of Mexican smallscale fisher's target species choices (for export markets). They too expected the price to significantly affect fisher's relocation of effort and although fishers did respond to changing prices, economic incentives were not the only driving force. Factors such as skill and personal background i.e., being a displaced person, played a role. In the Turks and Caicos spiny lobster and conch fisheries supplying US markets, economic rationality also did not entirely explain the observed behavior (Béné and Tewfik, 2001). They found that rather than intraseasonal price fluctuations seasonal fishing effort allocation decisions were complicated by various individual and collective characteristics, like peer pressure and diving abilities, as well as by the general socio-historical-cultural context of the fishery (Béné and Tewfik, 2001). Abernethy et al. (2007) add to this counterfactual with a case from Anguilla SSF showing that not all fishers sought to maximize profit. Similar to these studies our case, indicates that contextual characteristics of individual fishers play a stronger role in determining loaning and effort than price and economic incentives.

Financing (and the patron-client relations that ensue) has been argued to be a major influence on fishers' short-term extractive strategies in low-income tropical fisheries (Platteau, 1995; Carnaje, 2007; Johnson, 2010). However, we found no effect of the strength of real suki relationships on loan taking behavior. One possible reason is a lack of variation in our data. Most participants in our experiment were in an inflexible suki relationship (Table 3) and fishers in these types of agreements are likely to have been in them for a longer period of time. Longterm patron-client relations are those where both parties wish for them to continue over time (c.f. Merlijn, 1989). However, this seems to also create rigidity in the system as a whole. The complimentary data collected leads us to speculate that indebtedness and the flexibility of local financial arrangements may shape or constrain fisher's market related behavior. The fact that $60 \%$ of our respondents said they could not change patrons to follow better prices - seems to indicate that they are not used to responding to price dynamics. Longer, and thus more indebted and inflexible, fishing arrangements, as well as the preference of fishers for the suki system in general $(77 \%$ of fishers open-endedly preferred this source of finance over others e.g., banks, micro-credit) may promote path dependency in the fisheries constraining options to respond to future market or credit options.

Today's environmental governance strategies are increasingly moving their focus from extractive operations to seafood trade as a means to transition fisheries toward more sustainable trajectories. As such, increasing effort is put into marketbased tools like certifications schemes, eco-labeling (Fabinyi et al., 2018), and fishery improvement projects (Cannon et al., 2018). However, the rational economic justification for these systems (arguably more relevant to WEIRD contexts) often assumes away the importance of social relations like the suki system undermining actor's agency to coordinate and implement changes (Bailey et al., 2016). While it can be useful to conceptually reduce markets to operational variables like price, catch and demand, as we did within the experimental design, it has the potential effect of dislocating the market concept from the social relations that shape resource governance (Bennett, 2005).

\section{Why Did Men Go "Big Big Big"?}

One might expect the results we see - where women are much less likely to go for the bigger loan option - to be due to gender differences in financial risk-taking. However, according to our financial risk elicitation task, women were not less financially risk-seeking than men in our sample. In fact, no major gendered differences in individual, fishing or household related characteristics were found. Women and men in the sample used similar engine sizes, boat lengths, and are equally spread across gear types. The only significant gender difference amongst the collected complimentary data was the interpretation of the experimental variables. When asked how many liters of fuel a big or smaller trip in the experiment would need there is a significant difference between men and women $(p<0.001)$. Women interpreted on average half the number of liters as men for both the bigger and smaller trip. Likewise, for catch rates women estimated significantly lower catch rates representing the experimental values of 5,10 , and $20(p<0.001)$. For a catch rate of 20 , men on average thought of landing three times the amount of fish (KG) than women.

So why do we see these gender difference in our results if it is not financial risk aversion? One possible explanation is the fact that we captured only one type of risk in the elicitation task - yet there are other types of risk domains where men and women may differ, such as physical or health risks (Courtenay, 2000; Deleire and Levy, 2001). As such, respondents' degree of risk taking may be highly domain specific; that is, financial risk aversion may not correlate with preferences associated with physical risk (Courtenay, 2000; Deleire and Levy, 2001; Weber et al., 2002). This might explain our observations. Women may be less willing to take a bigger or longer trip (associated with a big loan) due to the increased physical risk this type of trip involves. Thus, they imagine landing less fish and needing less fuel. Women's interpretations of trip durations, distances, and fishing grounds were almost identical to men, but they might be more averse to spending the average $10 \mathrm{~h}$ a day at sea $( \pm 5 \mathrm{~h} \mathrm{SD})$ the typical fisher in our sample takes with a bigger fuel loan. Additionally, we carried out the experiments during habagat, which brings wet and stormy weather, increasing the physical risk of fishing.

Fisherwomen might be more physically risk averse but there might be a further and/or corresponding explanation to our observed gender differences. The goals of peoples' decisions in particular situations vary as a function of the personality and culture of the decision maker (Weber and Lindemann, 2007). Thus, we believe it is likely we are seeing the effect of cultural role-based decision modes, where participants took the social roles associated with gender in this area of the Philippines into the experiment and, as a result, the associated obligations (ibid). In focus group discussions when fishers, buyers and dryers (both men and women) were asked about gender differences in their work, six out of seven sitios all repeated that there is a difference in fishing but not in trade. 
The words "heavy," "strength," and "hard" were continuously repeated is these sitios in association with fishermen's' work and the word "lighter" for fisherwomen. Three sitios concurred that women cannot go out as often or as long as men. "Men are braver to go to sea than women" (Focus group participant, Malangabang, 2017). Other studies from fishing communities in the Philippines show that men are conceived of as the financial supporter and bearer of heavy workloads while women deal with child rearing and the household work (Siason, 2000). This may limit the time they have available to go on the bigger fishing trips. The social construct of masculinity potentially pushes men to go big during the experiment - in Palawan, Luzon and the Central Visayas (all in the Philippines) previous studies discuss the displays of masculine identity through the physical rigors of the sea-going occupation and lifestyle of fishing - "fishing is a gamble and an opportunity for male fishermen to demonstrate their masculinity, economic prowess, and value" pg. 519 (Dumont, 1992; Russell, 1997; Fabinyi, 2007).

\section{Post-experiment Hindsight: The Roles of Risk, Price, and Finance in Fishing}

In hindsight, we realize we limited our analysis of the full dataset due to the experimental design. By reusing the same catch-rate sequence for each session, with a different sequence for bigger and smaller fuel loans, we deterministically linked catch rate experience to the decision made (thus catch was not independent of choice). This created a nonrandom diversity in experiment experiences, which became exponentially more diverse throughout the experiment. We could only properly control for this effect up to round 4 of the experiment, which is why we could not make use of the whole time series of the experiment in the regression analyses. Note however, that we could still use the full data set when we analyzed the average treatment effects of price changes [see section "The Main Hypothesis- Price (Treatment) Effect"].

Although we tried different risk framings in the experiment, to account for the possibility that the abstract risk frame potentially did not capture risk preferences for fishing, our results showed no differences. Further research could involve investigating the best methods to capture different risk domains and areas of risk important in an SSF context. As noted above, fishing activities are not just affected by financial risk but involve high physical risk and sometimes social risk. For example- masculinity, failing to prove your maleness through fishing may hinder your social status amongst community members. A better understanding of gender-related results could be captured through assessing various domains. The concept of risk propensity still sees no academic consensus on its definition nor measurement.

Our experimental results could not identify an effect of price changes in fisher behavior. We believe this is in part due to the short-term nature of the time frame employed (which was trip based) - though in other literature fishers' behavior is not explained by prices even at seasonal scales (Béné and
Tewfik, 2001). Complimentary data collection did not detect any fishing behavior responses to price changes, though price fluctuations and uncertainty, even on a daily basis, were well registered amongst fishers. No sitios mentioned fishing in certain habitats, and locations based on price. The only response to price changes fishers mentioned in interviews related to switching patrons to those who offered higher prices - but only if their loans were paid off.

Our results may be proof that short-term price increases (as incorporated in our experiment) may not induce tactical behavioral changes in marine resource extraction. If this is the case, the simulated impact of the global market on fishers' behavior may not be observable in the short-term. In French Guyana, Béné (1996) identified a global market response in fishing effort only over a 13 years period, while seasonal strategies were still maintained in each fishing season. Fishers can be relatively constrained by their traditions and/or tendencies in response to short-term opportunities despite potential gains (Béné and Tewfik, 2001).

The literature review around this discussion suggests that while our study provided novel information on the impact of patron-client relationships on fisher's tactical decisions, it remains unclear how market integration affects extractive behavior over time, and in turn what the sustainability implications of this are in SSF. The role of patrons and the financing they provide remain key variables of interest for understanding this, but our work shows the need to find ways to incorporate longer time-scales into our examination of behavior. We invite reflections and discussion on how to capture such longer-term structural or strategic decisions in relation to changing markets, experimentally or using other methods.

\section{CONCLUSION}

In general, we believe the lack of price response supports the narrative that in the short-term fishers are constrained in their capacity to respond to market incentives. They develop and use fishing strategies in response to the market or regulatory constraints they encounter within their particular social, cultural, and economic contexts. They appear to bring these constraints in the form of gender roles into the experiment. In cash poor environments it can be difficult to adjust strategies even if there is potential gains from such a change - but also, fishers with the technical and capital capacity to change often do not in the short-term (e.g., Béné and Tewfik, 2001). Developing theoretical and empirical knowledge on the connections between seafood trade and SSF dynamics is increasingly important amid insatiable global markets, as there is evidence that many fisheries have crossed ecological thresholds to meet demands and high price incentives (Kooiman et al., 2005; Béné et al., 2010). Outcomes of global markets are filtered by context specific conditions at the local fishery scale (Crona et al., 2016). However, conventional fishery management often simplifies or ignores this, especially the complex power relations intertwined with fishing capital access, local fish trading agreements, and market pressures that impact fisher's extraction (Kininmonth et al., 2017). Our somewhat 
unexpected findings are important as they highlight gaps in our understanding of human behavior in the fishery context, and illustrates that "conventional truths" of fishers' responses perpetuated in scholarly fields may need to be challenged in order to achieve truly sustainable governance strategies.

With regards to governance insights, the results suggest a path dependency in credit, and loan relations due to longstanding relations. Policies that aim to introduce new micro-credit or finance schemes to coastal communities could help families pay back existing loans as part of the program. This would limit the continued influence of informal options and debt cycles, creating room for new choices and options within the fishing community. However, we also highlight that capacities to act can be influenced by social relations. These relational influences are likely to affect fishers' decision-making and should be accounted for when implementing policies, as they represent potential leverage points to intervene in the system (see also Drury O'Neill et al. (2019) for a deeper discussion on this topic). The fact that gender appears to influence fisher responses highlights the deeply cultural responses people in a fishery may have to interventions. Finding ways to account for such cultural perceptions in interventions may lead to fruitful governance experimentations, such as engaging with masculinity ideals to influence male fishers into patrolling or reporting harmful illegal activities.

\section{ETHICS STATEMENT}

This study was carried out in accordance with the recommendations of the ethics committee at the Stockholm Resilience Centre with written and/or oral informed consent from all subjects. Before any interviews or experiments took place all subjects were informed of the purpose and intent of the research and all subjects gave either written or oral informed consent in accordance with the Declaration of Helsinki. The protocol and plain language statement was approved by the ethics committee at the Stockholm Resilience Centre.

\section{REFERENCES}

Abernethy, K. E., Allison, E. H., Molloy, P. P., and Côté, I. M. (2007). Why do fishers fish where they fish? Using the ideal free distribution to understand the behaviour of artisanal reef fishers. Can. Fish. Aquat. Sci. 64, 1595-1604. doi: 10.1139/f07-125

Andersson, J., and Ngazi, Z. (1998). Coastal communities' production choices, risk diversification, and subsistence behaviour: responses in periods of transititon a case study from Tanzania. Ambio 27, 686-693.

Bailey, M., Bush, S., Oosterveer, P., and Larastiti, L. (2016). Fishers, fair trade, and finding middle ground. Fish. Res. 182, 59-68. doi: 10.1016/j.fishres.2015.11.027

Béné, C. (1996). Effects of market constraints, the remuneration system, and resource dynamics on the spatial distribution of fishing effort. Can. J. Fish Aquat. Sci. 53, 563-571. doi: 10.1139/f95-212

Béné, C., Arthur, R., Norbury, H., Allison, E. H., Beveridge, M., Bush, S., et al. (2016). Contribution of fisheries and aquaculture to food security and poverty reduction: assessing the current evidence. World Dev. 79, 177-196. doi: 10. 1016/j.worlddev.2015.11.007

Béné, C., Lawton, R., and Allison, E. H. (2010). "Trade matters in the fight against poverty": narratives, perceptions, and (lack of) evidence in the case of fish trade in Africa. World Dev. 38, 933-954. doi: 10.1016/j.worlddev.2009.12.010

\section{AUTHOR CONTRIBUTIONS}

All authors conceived and designed the research, and wrote the manuscript. ED, TL, TD, and $\mathrm{BC}$ designed the experiments and analyzed the data. $\mathrm{ED}, \mathrm{BC}$, and $\mathrm{AF}$ collected the data.

\section{FUNDING}

This work was made possible through the generous contribution of SIDA (The Swedish International Development Cooperation Agency) through grant number 1425704, by MISTRA funding to the Stockholm Resilience Centre, and funding to the Global Economic Dynamics and the Biosphere program by the ErlingPersson Foundation.

\section{ACKNOWLEDGMENTS}

We would like to sincerely thank the field team "Team Gorgeous," who enabled these experiments to take place. Jen, Jelai, and $\mathrm{Madz}$ were irreplaceable during this work and it was thanks to their diligence, abilities, and kindness we were able to carry out this study. Their energies created a safe and conducive learning and research space for everybody involved. Our heartfelt thanks to our honorary parents whom looked after us so well - Tito Alo and Tita Gina. Their support and care in the field were absolutely fundamental to this work. Finally, a big thanks to all the participants, the fishers and traders, who took time out of their busy lives to help us to learn.

\section{SUPPLEMENTARY MATERIAL}

The Supplementary Material for this article can be found online at: https://www.frontiersin.org/articles/10.3389/fmars. 2019.00491/full\#supplementary-material

Béné, C., and Tewfik, A. (2001). Fishing effort allocation and fishermen's decision making process in a multi-species small-scale fishery: analysis of the conch and lobster fishery in turks and Caicos Islands. Hum. Ecol. 29, 157-186.

Bennett, E. (2005). Gender, fisheries and development. Mar. Policy 29, 451-459.

Berkes, F., Hughes, T. P., Steneck, R. S., Wilson, J. A., Bellwood, D. R., Crona, B., et al. (2006). Globalization, roving bandits, and marine resources. Science 311, 1557-1558. doi: 10.1126/science. 1122804

Brewer, T. D. (2011). Coral reef fish value chains in Solomon Islands: Market Opportunities and Market Effects on Fish Stocks. Available at: https://spccfpstore1.blob.core.windows.net/digitallibrary-docs/files/58/581b4f 2314a4ebc894154e58e4ae5258.pdf?sv=2015-12-11\&sr=b\&sig=xTWMeYexYW oeCAN\%2F1mhICNDoszYxbihdRwaYv\%2Bl2UEo\%3D\&se=2020-01-21T10\% $3 \mathrm{~A} 13 \% 3 \mathrm{~A} 08 \mathrm{Z} \& \mathrm{sp}=\mathrm{r} \& \mathrm{rscc}=$ public $\% 2 \mathrm{C} \% 20 \mathrm{max}$-age $\% 3 \mathrm{D} 864000 \% 2 \mathrm{C} \% 20 \mathrm{max}-$ stale\%3D 86400\&rsct=application\%2Fpdf\&rscd=inline $\% 3 B \% 20$ filename $\% 3 \mathrm{D} \%$ 22Brewer_11_FishValue_SolomonIs.pdf\% (accessed October 20, 2016).

Cannon, J., Sousa, P., Katara, I., Veiga, P., Spear, B., Beveridge, D., et al. (2018). Fishery improvement projects: performance over the past decade. Mar. Policy 97, 179-187. doi: 10.1016/j.marpol.2018.06.007

Cardenas, J. C., and Carpenter, J. (2013). Risk attitudes and economic wellbeing in Latin America. J. Dev. Econ. 103, 52-61. doi: 10.1016/j.jdeveco.2013. 01.008 
Carnaje, G. P. (2007). Contractual Arrangements in Philippine Fisheries. Quezon: Philippine Institute for Development Studies (PIDS).

Carpenter, J., and Seki, E. (2011). Do social preferences increase productivity? Field experimental evidence from fishermen in Toyama Bay. Econ. Inquiry 49, 612-630. doi: $10.1111 / j .1465-7295.2009 .00268 . x$

Charness, G., and Gneezy, U. (2012). Strong evidence for gender differences in risk taking. J. Econ. Behav. Organ. 83, 50-58. doi: 10.1016/j.jebo.2011.06.007

Courtenay, W. H. (2000). Constructions of masculinity and their influence on men's well-being: a theory of gender and health. Soc. Sci. Med. 50, 1385-1401. doi: 10.1016/s0277-9536(99)00390- 1

Crona, B., Basurto, X., Squires, D., Gelcich, S., Daw, T. M., Khan, A., et al. (2016). Towards a typology of interactions between small-scale fisheries and global seafood trade. Mar. Policy 65, 1-10. doi: 10.1016/j.marpol.2015.11.016

Crona, B., Holt, T., Petersson, M., Daw, T. M., and Buchary, E. (2015). Using social-ecological syndromes to understand impacts of international seafood trade on small-scale fisheries. Glob. Environ. Change 35, 162-175. doi: 10.1016/ j.gloenvcha.2015.07.006

Croson, R., and Gneezy, U. (2009). Gender differences in preferences. J. Econ. Literature $47,448-474$.

Davis, W. G. (1973). Social Relations in a Philippine Market: Self-Interest and Subjectivity. Berkeley, CA: University of California Press.

Deleire, T., and Levy, H. (2001). "Gender, occupation choice and the risk of death at work," in National Bureau of Economic Research, Working Paper No. (8574). Cambridge, MA.

Drury O'Neill, E., Crona, B., Ferrer, A. J. G., and Pomeroy, R. (2019). From typhoons to traders: the role of patron-client relations in mediating fishery responses to natural disasters. Environ. Res. Lett. 14:045015. doi: 10.1088/17489326/ab0b57

Drury O'Neill, E., Crona, B., Ferrer, A. J. G., Pomeroy, R., and Jiddawi, N. (2018). Who benefits from seafood trade? A comparison of social and market structures in small-scale fisheries. Ecol. Soc. 23:12. doi: 10.5751/ES-10331-230312

Dumont, J. P. (1992). Visayan Vignettes: Ethnographic Traces of a Philippine Island. Chicago: University of Chicago Press.

Eggert, H., and Lokina, R. B. (2007). Small-scale fishermen and risk preferences. Mar. Resour. Econ. 22, 49-67. doi: 10.1086/mre.22.1.42629535

Eggert, H., and Martinsson, P. (2004). Are commercial fishers risk-lovers? Land Econ. 80, 550-560.

Fabinyi, M. (2007). Illegal fishing and masculinity in the Philippines: a look at the Calamianes Islands in Palawan. Philipp. Stud. 55, 509-529.

Fabinyi, M., Dressler, W. H., and Pido, M. D. (2018). Moving beyond financial value in seafood commodity chains. Mar. Policy 94, 89-92. doi: 10.1016/j.marpol. 2018.04.033

Ferolin, M. C., and Dunaway, W. A. (2013). Globalized fisheries, depeasantization and debt bondage in Philippine seafood exporting. Int. J. Hum. Soc. Sci. 3, $45-56$.

Ferrer, A. J. G. (2009). Evaluation of Fisheries Management Options for the Visayan Sea, Philippines: The Case of Northern Iloilo. Singapore: Economy and Environment Program for Southeast Asia.

Ferrer, A. J. G. (2016). "Fisheries management options for visayan sea, philippines: the case of northern Iloilo," in Marine and Coastal Ecosystem Valuation, Institutions, and Policy in Southeast Asia, eds N. Olewiler, H. A. Francisco, and A. J. G. Ferrer Singapore: Springer, 287-309. doi: 10.1007/978-981-10-014 $1-3 \_14$

Ferse, S. C. A., Glaser, M., Neil, M., and Schwerdtner Máñez, K. (2014). To cope or to sustain? Eroding long-term sustainability in an Indonesian coral reef fishery. Reg. Environ. Change 14, 2053-2065. doi: 10.1007/s10113-0120342-1

Fulton, E. A., Smith, A. D. M., Smith, D. C., and van Putten, I. E. (2011). Human behaviour: the key source of uncertainty in fisheries management. Fish Fish. 12, 2-17. doi: 10.1111/j.1467-2979.2010.00371.x

Garzon, C. A., Rey, M. C., Sarmiento, P. J., and Cardenas, J. C. (2016). Fisheries, fish pollution and biodiversity: choice experiments with fishermen, traders and consumers. Econ. Politica 33, 333-353. doi: 10.1007/s40888-0160041-3

Gössling, S. (2003). Market integration and ecosystem degradation: is sustainable tourism development in rural communities a contradiction in terms? Environ. Dev. Sustain. 5, 383-400.
Hardiman, D. (1996). Feeding the Baniya: Peasants and Usurers in Western India. Oxford: Oxford University Press.

Harrison, G. W., and List, J. A. (2004). Field experiments. J. Econ. Literature 42, 1009-1055.

Haushofer, J., and Fehr, E. (2014). On the psychology of poverty. Science 344, 862-867. doi: 10.1126/science. 1232491

Hendriks, M. (1994). "Trade arrangements and interlinked credit in the Philippines," in Financial Landsacpes Reconstructed- the Fine Art of Mapping Development, eds F. J. A. Bouman, and O. Hospes Boulder: Westview Press.

Henrich, J., Boyd, R., Bowles, S., Camerer, C., Fehr, E., Gintis, H., et al. (2001). In search of homo economicus: behavioral experiments in 15 small-scale societies. Am. Econ. Rev. 91, 73-78. doi: 10.1257/aer.91.2.73

Hernando, C. M. (2005). The socio-economics of the visayan sea fisheries sector: focus on marketing and credit. Danyag J. Soc. Sci. Hum. 5, 175-186.

Iloilo Provincial Annual Profile (2015). Province of Iloilo Available at: http://www. iloilo.gov.ph/iloilo-provincial-annual-profile (accessed May 29, 2015).

Jentoft, S., and Eide, A. (2011). Poverty Mosaics: Realities and Prospects in SmallScale Fisheries. Berlin: Springer Science \& Business Media.

Johnson, D. S. (2010). Institutional adaptation as a governability problem in fisheries: patron-client relations in the Junagadh fishery. India Fish Fish. 11, 264-277. doi: 10.1111/j.1467-2979.2010.00376.x

Kagel, J. H., and Roth, A. E. (2016). The Handbook of Experimental Economics, the Handbook of Experimental Economics. Princeton, NJ: Princeton university press.

Kahneman, D., and Tversky, A. (2013). "Prospect theory: an analysis of decision under risk." in Handbook of the Fundamentals of Financial Decision Making, eds L. C. MacLean, W. T. Ziemba (Singapore: World Scientific Publishing Company), 99-127

Kininmonth, S., Crona, B., Bodin, Ö, Vaccaro, I., Chapman, L., and Chapman, C. (2017). Microeconomic relationships between and among fishers and traders influence the ability to respond to social-ecological changes in a small-scale fishery. Ecol. Soc. 22:26. doi: 10.5751/ES-08833-220226

Kooiman, J., Bavinck, M., Jentoft, S., and Pullin, R. (eds) (2005). Fish for Life. Amsterdam: Amsterdam University Press.

Lindahl, T., and Jarungrattanapong, R. (2018). Avoiding Catastrophic Collapse in small Scale Fisheries through Inefficient Cooperation: Evidence from a Framed Field Experiment. Stockholm: The Beijer Insititute of Ecological Economics.

Máñez, K. S., and Ferse, S. C. A. (2010). The history of makassan trepang fishing and trade. PLoS One 5:e11346. doi: 10.1371/journal.pone.0011346

Mela, C. F., and Kopalle, P. K. (2002). The impact of collinearity on regression analysis: the asymmetric effect of negative and positive correlations. Appl. Econ. 34, 667-677. doi: 10.1080/00036840110058482

Merlijn, A. G. (1989). The role of middlemen in small-scale fisheries: a case study of sarawak, Malaysia. Dev. Change 20, 683-700. doi: 10.1111/j.1467-7660.1989. tb00362.x

Miñarro, S., Forero, G. N., Reuter, H., and van Putten, I. E. (2016). The role of patron-client relations on the fishing behaviour of artisanal fishermen in the Spermonde Archipelago (Indonesia). Mar. Policy 69, 73-83. doi: 10.1016/j. marpol.2016.04.006

NEDA, (2011). Coastal, Aquatic and Fishery Resources Development along the Influence Areas of the Visayan Sea, 2011-2020. Iloilo: National Economic and Development Authority Region VI.

Noussair, C. N., van Soest, D., and Stoop, J. (2015). Cooperation in a dynamic fishing game: a framed field experiment. Am. Econ. Rev. 105, 408-413. doi: 10.1257/aer.p20151018

Nurdin, N., and Grydehøj, A. (2014). Informal governance through patron-client relationships and destructive fishing in Spermonde Archipelago, Indonesia. J. Mar. Island Cult. 3, 54-59. doi: 10.1016/j.imic.2014.11.003

Platteau, J.-P. (1989). Penetration of capitalism and persistence of small-scale organizational forms in third world fisheries. Dev. Change 20, 621-651. doi: 10.1111/j.1467-7660.1989.tb00360.x

Platteau, J.-P. (1995). A framework for the analysis of evolving patron-client ties in agrarian economies. World Dev. 23, 767-786. doi: 10.1016/0305-750x(95) 00011-z

Pollnac, R. B., and Crawford, B. R. (2000). Assessing behavioral aspects of coastal resource use. Coastal Management Report \#2226. (Narragansett: University of Rhode Island), 139. 
Pomeroy, R. S. (1990). The economics of production and marketing in a small scale fishery: Matalom, Leyte, Philippines. Diss. Abstr. Int. A, Hum. Soc. Sci. 50, 3001-3002.

Pomeroy, R. S. (1992). Fish marketing in the Philippines: is the "suki" symbiotic or parasitic? Naga 15, 13-14.

Purcell, S. W., Crona, B., Lalavanua, W., and Eriksson, H. (2017). Distribution of economic returns in small-scale fisheries for international markets: a valuechain analysis. Mar. Policy 86, 9-16. doi: 10.1016/j.marpol.2017.09.001

Ripley, B. D. (2001). The R project in statistical computing. MSOR Connect. 1, 23-25. doi: 10.11120/msor.2001.01010023

Ruddle, K. (2011). Informal" credit systems in fishing communities: issues and examples from vietnam. Hum. Organ. 70, 224-232. doi: 10.17730/humo.70.3. v4810k37717h9g01

Russell, S. D. (1997). Class identity, leadership style, and political culture in a Tagalog coastal community. Pilipinas 28, 79-95.

Salas, S., Sumaila, U. R., and Pitcher, T. (2004). Short-term decisions of small-scale fishers selecting alternative target species: a choice model. Can. J. Fish. Aquat. Sci. 61, 374-383. doi: 10.1139/f04-007

Schulze, W. D., d'Arge, R. C., and Brookshire, D. S. (1981). Valuing environmental commodities: some recent experiments. Land Econ. 57, 151-172.

Siason, I. M. (2000). Women in fisheries in the Philippines. Review of Women's Studies. Available at: http://pubs.iclarm.net/Pubs/Wif/wifasia/N4-06-Siason. pdf (accessed October 20, 2016).

Thanh, T. P. T., and Flaaten, O. (2012). Middlemen-Good for Resource and Fishermen? An Economic Analysis of a Common Fisheries Institution in Developing Countries. Page Visible Possibilities: The Economics of Sustainable Fisheries, Aquaculture and Seafood Trade. Dares Salaam: International Institute of Fisheries Economics and Trade (IIFET).

Wakker, P. P. (2010). Prospect Theory: For Risk and Ambiguity. Cambridge: Cambridge university press.

Weber, E. U., Blais, A., and Betz, N. E. (2002). A domain-specific risk-attitude scale: measuring risk perceptions and risk behaviors. J. Behav. Decis. Mak. 15, 263-290. doi: 10.1002/bdm.414

Weber, E. U., and Lindemann, P. G. (2007). "From intuition to analysis: making decisions with our head, our heart, or by the book," in Intuition in Judgment and Decision Making, eds H. Plessner, C. Betsch, and T. Betsch (Mahwah, NJ: Lawrence Erlbaum), 191-208.

Conflict of Interest Statement: The authors declare that the research was conducted in the absence of any commercial or financial relationships that could be construed as a potential conflict of interest.

Copyright (c) 2019 Drury O'Neill, Lindahl, Daw, Crona, Ferrer and Pomeroy. This is an open-access article distributed under the terms of the Creative Commons Attribution License (CC BY). The use, distribution or reproduction in other forums is permitted, provided the original author(s) and the copyright owner(s) are credited and that the original publication in this journal is cited, in accordance with accepted academic practice. No use, distribution or reproduction is permitted which does not comply with these terms. 